\title{
Meta-Analysis of Storm Water Impacts in Urbanized Cities Including Runoff Control and Mitigation Strategies
}

\author{
Pengfei Zhang ${ }^{1} \&$ Samuel T. Ariaratnam ${ }^{1}$ \\ ${ }^{1}$ School of Sustainable Engineering and the Built Environment, Arizona State University, Tempe, USA \\ Correspondence: Samuel T. Ariaratnam, School of Sustainable Engineering and the Built Environment, Arizona \\ State University, Tempe, Arizona 85287-3005, USA. Tel: 1-480-965-7399. E-mail: ariaratnam@asu.edu
}

Received: August 29, 2018

Accepted: October 5, 2018

Online Published: November 29, 2018

doi:10.5539/jsd.v11n6p27

URL: https://doi.org/10.5539/jsd.v11n6p27

\begin{abstract}
The rate of urbanization has been impacted by global economic growth. A strong economy results in more people moving to already crowded urban centers to take advantage of increased employment opportunities often resulting in sprawling of the urban area. More natural land resources are being exploited to accommodate these anthropogenic activities. Subsequently, numerous natural land resources such as green areas or porous soil, which are less flood-prone and more permeable are being converted into buildings, parking lots, roads and underground utilities that are less permeable to storm water runoff from rain events. With the diminishing of the natural landscape that can drain storm water during a rainfall event, urban underground drainage systems are being designed and built to tackle the excess runoff resulting from urbanization. However, the rapid pace of urbanization has profoundly affected the formation of urban runoff thus resulting in the existing underground drainage system being unable to handle current flow conditions. This paper discusses storm water impacts in urbanized areas globally by reviewing historical storm water events and mitigation strategies accompanied with runoff reduction performance that are considered simultaneously for the purpose of relieving the stress on underground drainage systems. It was found that the stormwater impact on ten selected typical urban areas were enormously destructive followed by billions of direct economy loss, fatalities, damaged properties and residents' relocations. Furthermore, the meta-analysis of selected six runoff mitigation methods indicated that the average runoff reduction percent ranged from $43 \%$ to $61 \%$ under different rain events in various installed sites across different event years.
\end{abstract}

Keywords: storm water runoff, mitigation methods, meta-analysis, flooding

\section{Introduction}

Storm water runoff, one of the most common and destructive results of natural disasters, often results in significant impacts to an urban environment during a major rain event. Of all-natural disasters, storm water induced flooding occurs frequently, extensively, massively and destructively. Not only does flooding inundate residential properties and people, but it often impacts food, farmlands, local businesses, communication systems, transportation arteries, and critical underground utilities. Since the beginning of 21 st century, significant flooding has occurred over 50 times around the world, displacing millions of people.

Storm water is referred to as rainfall or snowmelt that runs off impervious ground surfaces such as buildings, paved roads, parking lots and driveways and flows into manmade drainage infrastructures such as gutters, ditches, storm sewers, channels or streams (Penn and Parker 2011). Due to urbanization, the land exploitation rate has largely increased and consequently, surface vegetation covered areas and natural land preservation that could diminish the flooding impacts are removed and replaced with impervious material such as pavement and buildings. As a result, the discharge volume and frequency of runoff increases as runoff is unable to slowly filter into a land surface with higher imperviousness rate (Carson et al., 2010; Sun et al., 2013; Ohana-Levi et al., 2017). Furthermore, with poor maintenance and aged underground drainage systems, the actual drainage capacity may not even conform with the original design capacity. As runoff surges into drains, it often picks up motor oils, surface sediment, dirt and excess nutrients such as nitrogen and phosphorus through the drainage infrastructure. This deterioration in the quality of drainage infrastructure often results in clogging and fracturing induced by the carried pollutants. The effect is a decrease in the future performance of the drainage infrastructure. Often, the runoff increment due to urbanization has already surpassed the design capacity of the current drainage 
system. Many urban drainage systems have been struggling to handle excessive runoff. Subsequently, a question has been raised about whether the application of sustainable storm water mitigation strategies can alleviate the pressure on urban drainage systems and how good these are in terms of the performance of storm water runoff reduction. This paper discusses storm water impacts on urbanized areas through a review of historical incidents and runoff reduction strategies to improve storm water-resilience performance in urbanized areas. The runoff reduction performance associated with each strategy is discussed through the literature review. The predominant strategies for improving storm water runoff are defined follows:

Green Roof: Green roof is a runoff control strategy also referred to as eco-roof, living roofs, or garden roofs (Cutlip, 2006). The methodology for this strategy is to incorporate the planting of landscape onto building rooftops as shown in Figure 1. The primary objective of the finished roof is to absorb precipitation landed on the rooftop, temporarily store it and release it at a controllable speed facilitated by the water retention capabilities of planting soil (Graceson et al. 2013).

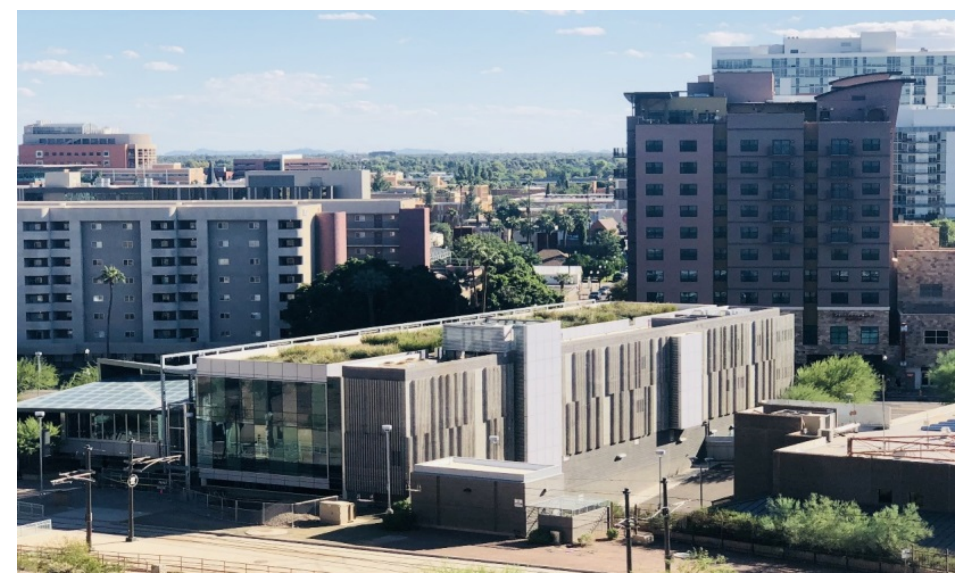

Figure 1. Green roof in Tempe, Arizona

Blue Roof: Blue roof is designed to retain rainwater at the roof top and release excess rainfall through orifices weirs, or other outlet devices that slowly discharge storm water during or after a rainfall event (NJDEP, 2017) The mechanism of finished Blue roof is to control the runoff leaving the rooftop at a slower speed than conventional roofs, and eventually reducing the peak flow rate and storm water runoff volume. Blue roof can either be constructed on a new building or as a retrofit, to an existing building as a runoff control strategy (NJDEP, 2017).

Rooftop Disconnection: Rooftop disconnection is a relatively straightforward runoff mitigation strategy that simply diverts the roof runoff into the gutter of downspouts from an impervious surface to pervious surfaces such as grasslands, shrubs and other landscape. In this way, the redirected runoff can be infiltrated, filtered, and treated prior to draining into a storm water conveyance system (Sample, 2013).

Swales: Swales are engineered vegetated ditches that can provide a stable route for storm water runoff and a low-cost drainage option for highways, farms, industrial sites and commercial areas (Struck et al. 2007). Barrett (2008) concluded that if the soil is permeable and the initial moisture is low, infiltration achieved by swales can approach $50 \%$ in semiarid regions. In other words, nearly half of the received rainfall will be retained on site.

Permeable Pavement: Permeable pavement, also called pervious pavement, is an innovative method of paving vehicle and pedestrian pathways that allows water to pass through the surface into the underlying soil layer through voids in the pavement. Figure 2 illustrates a parking lot paved with permeable pavement. The aim of permeable pavement is to mimic the pre-development hydrologic condition in which the storm water can be effectively delayed, and runoff volume can be largely reduced (Eckart et al., 2017). 


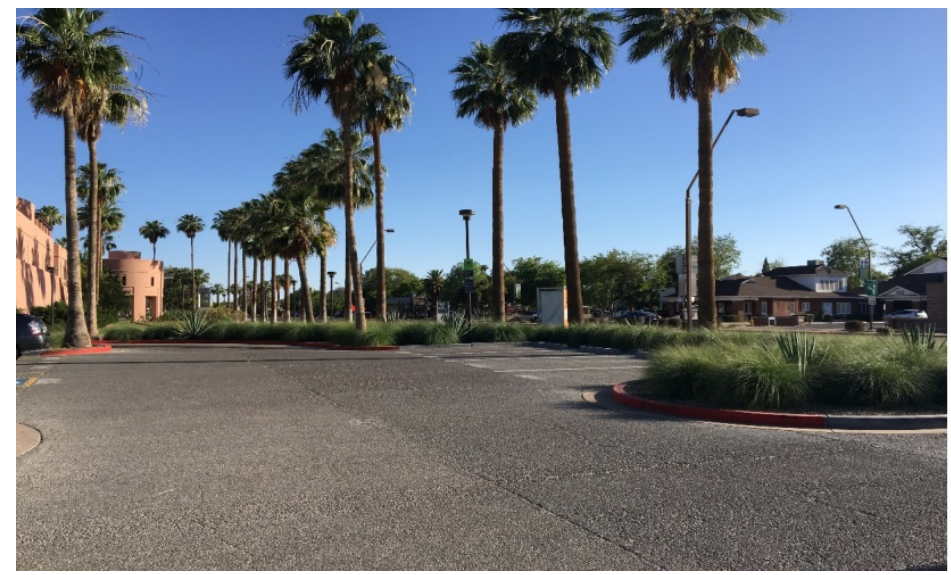

Figure 2. Permeable pavement in Tempe, Arizona

Bioretention (or Rain Garden): Bioretention is another way to mimic the movement of water before urban development and also release the water stress on urban drainage systems. A rain garden/bioretention is a shallow depression where native shrubs and flowers are planted. Figure 3 illustrates a typical bioretention used in Arizona. The main purpose is to temporarily hold and soak in rain water runoff that flows from rooftops, parking lots and driveways (Ahiablame et al., 2012; Selbig and Balster. 2010).

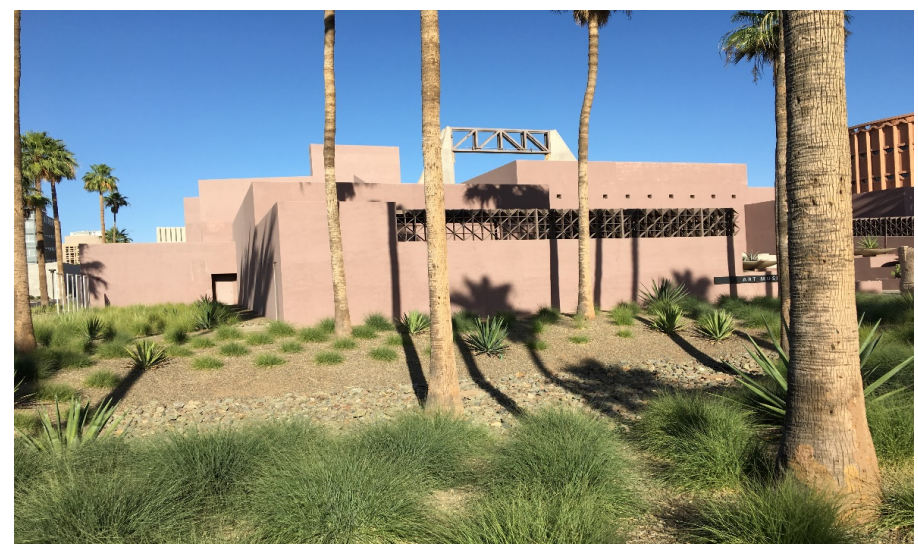

Figure 3. Bioretention in Tempe, Arizona

Drywell: Drywell is an underground facility that can collect runoff and recharge subsoil through an infiltration system (NJDEP, 2017). Drywell functions by combining water conveyance systems, such as vertical downspout or horizontal storm drain pipes, and water storage units, such as chambers or large dimension corrugate metal pipe, that are only used for storm water collection and storage.

Construction Wetlands: Constructed wetlands, also referred to as storm water wetlands, are designed for flood control purposes. Unlike a natural wetland, constructed wetlands perform fewer ecological functions. Despite that, constructed wetlands have achieved excellent performance in reducing runoff volume (Lenhart and Hunt. 2011).

\section{Previous Research}

\subsection{Urbanization Impact on Storm Water Runoff}

Urbanization is the transition outcome of a developing society, either from economic development or science development, and consequently, leading to more people living in rural areas moving to urban areas. To accommodate the population density living in urban areas, existing land resources are being utilized and converted into living spaces, transportation routes and recreational areas. As the urban area expands horizontally, more land areas such as forests, wetlands, and even rivers, which are less prone to runoff, are transformed to buildings, roads, and parking lots. The changes of runoff formation due to urbanization can be classified into two types: 1) infiltration capacity change and 2) storage capacity change. 


\subsubsection{Infiltration Capacity Change}

Various studies have demonstrated the effects of changing land cover types in urban areas on soil infiltration of water. Continuous growth of natural terrain coverage for residential, industrial, commercial and parking spaces results in existing land cover and permeable soils being disturbed and consequently, larger voids in the soil are compacted and sealed. As a result, the infiltration ability of the land area is often significantly diminished. Water balance refers to the flow of water in and out of a hydrological system. With decreasing permeability of urban areas, excessive rainwater is transformed into surface runoff to accommodate water balance.

Efforts have been made by scientists to evaluate the changing infiltration rate during different stages of urbanization including forest zones, agricultural zones and urbanized zones. Pitt et al. (1999) analyzed 153 urban soils and found that typical infiltration values for non-compacted clays and silts were $170 \mathrm{~mm} / \mathrm{hr}$., but only $10 \mathrm{~mm} / \mathrm{hr}$. for compacted clays and silts. Similarly, typical infiltration values for uncompacted sand sample were $380 \mathrm{~mm} / \mathrm{hr}$., but only $46 \mathrm{~mm} / \mathrm{hr}$. for compacted sands. Taylor et al. (2009) assessed the infiltration characteristics of soils in upper Waikato (New Zealand) under both pine forest and agriculture areas. The in-situ infiltration measurement revealed that the infiltration capacity of agriculture area (between 3 and $99 \mathrm{~mm} / \mathrm{hr}$.) was an order of magnitude less than the pine forest area $(121-1207 \mathrm{~mm} / \mathrm{hr}$.) The high measured infiltration value indicated that a higher precipitation event is required to generated surface runoff. Nazir and Sharma (2015) conducted hydraulic conductivity study in five forest covers in India and estimated the infiltration rate under both disturbed and undisturbed forest cover. By using the double ring infiltrometer method, the study indicated that the maximum infiltration value found in these five sites after the first five minutes was $512 \pm 30.1 \mathrm{~mm} / \mathrm{hr}$. in undisturbed forest. However, in the same type of forest except disturbed, it was $312 \pm 43.2 \mathrm{~mm} / \mathrm{hr}$. It was observed that the infiltration capability of soil decreased with the soil disturbance.

Likewise, additional studies were conducted in determining the general percentage of runoff increase due to urbanization induced infiltration changes. Jaber (2008) described concerns that storm water could bring to an urbanized setting including increased runoff, increased soil erosion, and impaired water quality. In a city built with impervious materials such as pavement and concrete, the runoff rate would be largely increased. Comparing a $75 \%$ to $100 \%$ impervious cover in a city to natural ground cover, more than $55 \%$ of the precipitation would transform into surface runoff in an urban zone, while only $10 \%$ of the precipitation would be converted as runoff in a natural ground cover area. The increased runoff in an urban area is attributed to the fact that the infiltration rate of impervious materials is relatively low. Subsequently, excessive water cannot filtrate into the underground effectively but rather converts as surface runoff (Huong and Pathirana, 2013). Makovic et al. (2014) claimed that $80 \%$ of rainfall water soaked into the soil and becomes part of subsoil water in natural terrains, while this situation is opposite in urban areas, where at least $80 \%$ of rainfall forms as runoff to wastewater disposal systems or rivers and only $20 \%$ soaks into the soil.

\subsubsection{Storage Capacity Change}

There are two relative terms to describe water storage, consisting of detention and retention. Detention means that moisture in the soil is detained as it makes its way into the groundwater or streamflow. Retention denotes that water is retained against gravitational forces and later conveyed into the atmosphere.

Forest soils are generally less dense than regular soil and have a greater capacity to store water. Anderson et al. (1976) reviewed soil-water storage experiments conducted by multiple scientists and researchers and tabulated the maximum soil-water storage under selected forest stands. The research results indicated that soil-water storage varies with root depth, soil texture, and types, ranging from 7-23 inches. Canopy interception, also known as retention capability, refers to the rainfall water retained by tree leaves and successfully evaporated. The rainfall that is not intercepted will fall as throughfall or streamflow on the forest floor. Hundecha and Bardossy (2004) modeled an afforestation scenario in the Rhine Basin in Southwest Germany and studied the land cover change effect on urban runoff. By comparing the runoff with the existing $40 \%$ forested scenario, containing more than $43 \%$ of agriculture, it was found that a $100 \%$ forested scenario would result in an average of $14 \%$ decrement in peak flow throughout the study season. Interception loss in forests was found to account for a substantial amount of loss in the total rainfall, Xiao and McPherson (2016) illustrated the surface water storage capacity of twenty tree species for a 40-yr period with different rainfall intensities and durations. The study indicated that tree leaves play a pivotal role in intercepting rainwater. During the leaf-on season, a 40 -yr Japanese zelkova tree can intercept $85 \%$ and $62 \%$ of rainfall for 5 and 25 -yr storm events, respectively. However, during the leaf-off season, interception drops to $26 \%$ and $25 \%$ for the same storm events.

Together with deforestation; however, urbanization has largely reshaped the drainage capacity of existing drain areas. In order to deal with the excess runoff, urban drainage infrastructures are designed to collect and transport 
urban surface runoff away from urban areas to the nearest water body or wastewater treatment plan for water recycling purposes (Zhou, 2014; Chocat et al., 2007). An ideal drainage system can effectively remove the runoff generated from streets, parking lots, rooftops, and other surface features at a rate faster than the rainfall accumulation rate. Litter and soil erosion in urbanized areas can clog drainage systems such as gutters, drain manholes and catch basins, thereby decreasing the resulting drainage capability. Wallace (2013) concluded that clogging damages the drainage system to the point that it loses its design capacity resulting in increased localized flooding. Furthermore, extreme weather is the key cause of urban flooding since the drainage systems designed or constructed years ago typically underestimated the rainfall severity and frequency, leading to less relief time and space for drainage systems under frequent rainfall events to maintain water balance in the hydrology system.

\subsection{History of Storm Water Impacts in Urban Areas}

Urbanization induced impacts on runoff is reflected by increased runoff rates and volumes, decreased infiltration, decreased groundwater recharge and base flow (Ahiablame et al., 2012). Meanwhile, the economic impact of urban runoff cannot be neglected. Table 1 presents details on urban runoff impacts in several major cities through examination of ten historical events from 2012 to 2017 that had major flooding. Displacement of residents and significant economic losses were experienced in each of these significant flooding events with failure of the urban drainage infrastructure being a common issue.

Table 1. Review of historic event about stormwater impacts on urban areas

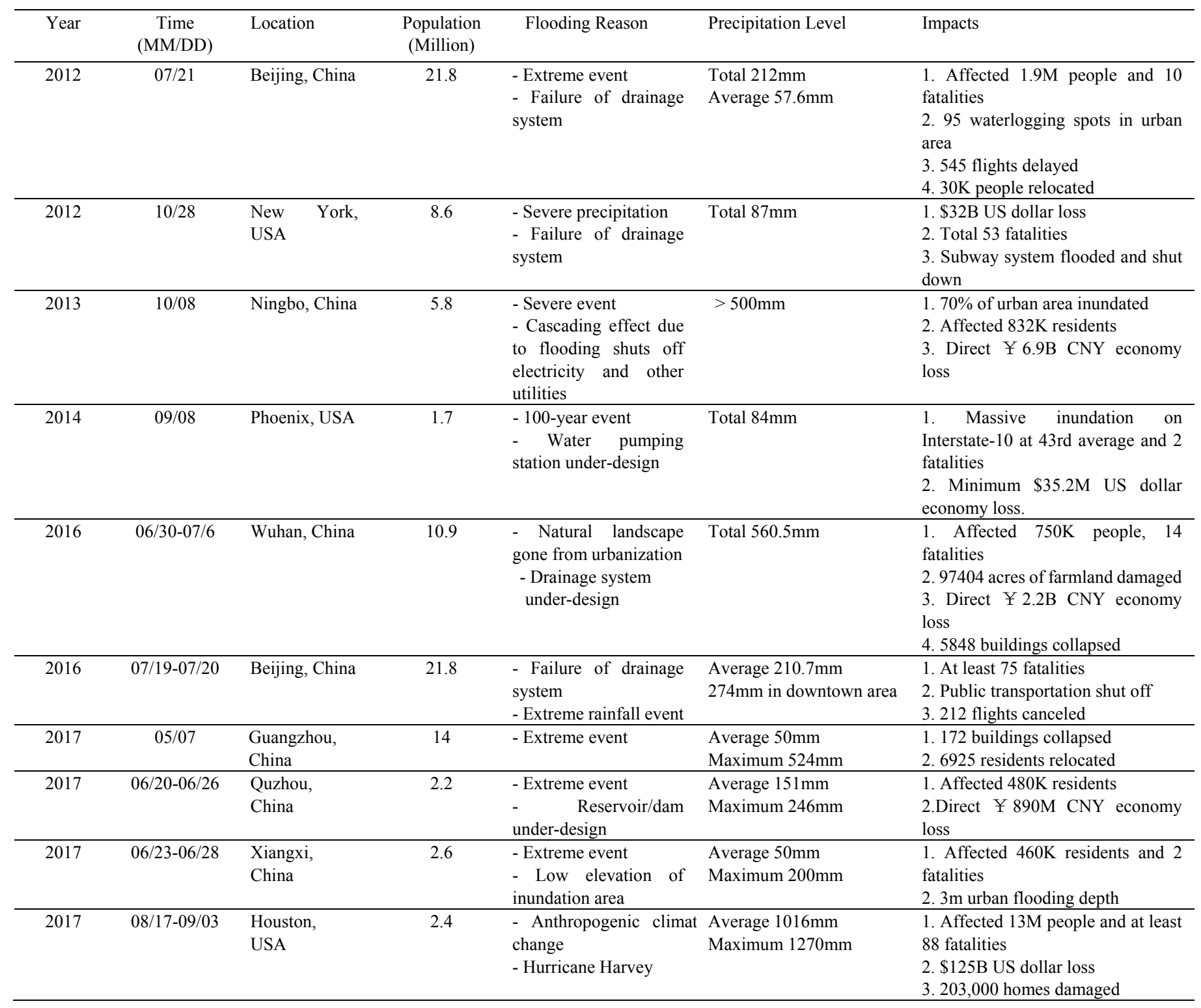




\subsection{Strategies for Better Storm Water-Resilience Performance}

Low impact development (LID) consists of various storm water runoff mitigation practices that are aimed at preserving or mimicking natural drainage processes (EPA, 2012). Successful implementation of a LID can retain water and encourage it to soak into the subsoil rather than allowing it to freely flow into the street as runoff. Multiple storm water mitigation strategies are previously discussed.

\section{Meta-Analysis}

To gain a better understanding of the effectiveness of various mitigation strategies in reducing urban runoff, a meta-analysis was conducted. Data from previously published research was analyzed in terms of different mitigation methods. For this analysis, six runoff control and mitigation strategies were considered. It was found that runoff reduction performance of Green Roof is optimal with an average runoff reduction rate of $61.2 \%$ followed by Permeable pavement and Bioretention at $56.4 \%$ and $52.9 \%$, respectively. Runoff reduction is calculated by using the water balance method to determine water differences between inflow and outflow and quantifying the percentage water retained or lost in a media. Two types of runoff were considered in this research including infiltration excess runoff and saturation excess runoff, which are the two typical scenarios used to represent runoff in an urban area. Infiltration excess runoff is formed once the rainfall intensity is larger than the water conductivity of contact surface including rooftops, roads, and parking lots. In this way, any excess water that the contact surface cannot infiltrate into the subsoil becomes runoff. For example, the rate of water flowing into a manhole or other drainage system has exceeded the system's ability to absorb or release it during an extreme event. For saturation excess runoff, the storage capacity of the drainage system has reached a threshold such that it cannot physically contain more water. For example, urban storm water that is collected by drainage systems such as gutters, catch basins, and underground pipes, have to be treated by a wastewater treatment plant (WTP) prior to being released into a nearby water body. However, the runoff volume collected by the drainage system could be beyond the capacity of the WTP. Given that the daily treatment capacity is limited for each WTP, the treatment system may stop receiving untreated water considering the overload impact. Subsequently, runoff that is ready for treatment may have no place to go but to stay in the drainage system or urban surface.

Table 2 presents a comprehensive summary analysis of laboratory and field research of the various runoff control and mitigation strategies. Forty-four studies from 2001-2017 are analyzed demonstrating implementation in various countries and climates.

Table 2. Summary of mitigation performance for alternative methods

\begin{tabular}{cccccl}
\hline $\begin{array}{c}\text { Mitigation } \\
\text { Method }\end{array}$ & $\begin{array}{c}\text { Site } \\
\text { Location }\end{array}$ & Year & $\begin{array}{c}\text { Average Runoff } \\
\text { Reduction (\%) }\end{array}$ & $\begin{array}{c}\text { Infiltration } \\
\text { Capability (mm/h) }\end{array}$ & Reference \\
\hline Green Roof & East Lansing, MI & 2004 & 85 & N/A & VanWoert et al. 2004 \\
(14 Studies) & Vancouver, Canada & 2005 & 67 & N/A & Connelly and Liu. 2005 \\
& Brussels, Belgium & 2006 & 54 & N/A & Mentens et al. 2006 \\
& East Lansing, MI & 2007 & 80.8 & N/A & Getter et al. 2007 \\
& Pittsburgh, PA & 2008 & 70 & N/A & Bliss et al. 2008 \\
& Austin, TX & 2008 & 66 & N/A & Simmons et al. 2008 \\
& Vancouver, Canada & 2010 & 29 & N/A & Roehr and Kong. 2010 \\
& Auckland, New Zealand & 2010 & 82 & N/A & Voyde et al. 2010 \\
& Shanghai, China & 2010 & 55 & N/A & Roehr and Kong. 2010 \\
& Southfield, MI & 2011 & 68.25 & N/A & Carpenter and Kaluvakolanu. 201 \\
& Storrs, CT & 2011 & 51 & N/A & Gregoire and Clausen. 2011 \\
& Sheffield, UK & 2012 & 50 & N/A & Stovin et al. 2012 \\
& Newport, UK & 2013 & 44 & N/A & Graceson et al. 2013 \\
& St. Louis, MO & 2015 & 50 & N/A & Morgan et al. 2015
\end{tabular}




\begin{tabular}{|c|c|c|c|c|c|}
\hline Permeable & Coventry, UK & 1999 & 59.5 & $\mathrm{~N} / \mathrm{A}$ & Bond et al. 1999 \\
\hline \multirow{10}{*}{$\begin{array}{l}\text { Pavement } \\
\text { (11 Studies) }\end{array}$} & Athens, GA & 2006 & 93 & N/A & Dreelin et al. 2006 \\
\hline & Coastal Plain, $\mathrm{NC}$ & 2007 & 100 & N/A & Bean et al. 2007 \\
\hline & Sydney, Australia & 2010 & $\mathrm{~N} / \mathrm{A}$ & $20+$ & Ball and Rankin. 2010 \\
\hline & Ontario, Canada & 2011 & 43 & N/A & Drake et al. 2014 \\
\hline & Australia and abroad & 2013 & 81 & N/A & Imteaz et al. 2013 \\
\hline & Beijing, China & 2015 & 34.8 & N/A & Yang et al. 2015 \\
\hline & Edinburgh, UK & 2016 & 40 & N/A & Alsubih et al. 2016 \\
\hline & Cleveland, $\mathrm{OH}$ & 2018 & 34.5 & N/A & Winston et al. 2018 \\
\hline & Songpa, Korea & 2018 & 48 & $\mathrm{~N} / \mathrm{A}$ & Shafique et al. 2018 \\
\hline & Peoria, IL & 2016 & 30 & $\mathrm{~N} / \mathrm{A}$ & Riemann. 2016 \\
\hline \multirow{11}{*}{$\begin{array}{c}\text { Rain Garden } \\
\text { (Bioretention) } \\
\text { (11 Studies) }\end{array}$} & Kinston, East NC & 2008 & 53 & $\mathrm{~N} / \mathrm{A}$ & Collins et al. 2008 \\
\hline & Southfield, MI & 2008 & N/A & $102-508$ & Carpenter and Hallam. 2008 \\
\hline & Minneapolis, MN & 2009 & N/A & $30-720$ & Asleson et al. 2009 \\
\hline & $\mathrm{NC}$ and $\mathrm{MD}, \mathrm{US}$ & 2009 & 35 & N/A & Li et al. 2009 \\
\hline & Edison, NJ & 2010 & N/A & $20-1500$ & Stander et al. 2010 \\
\hline & Seattle, WA & 2010 & 61 & $\mathrm{~N} / \mathrm{A}$ & Chapman and Horner. 2010 \\
\hline & Nashville, NC & 2012 & 40 & $\mathrm{~N} / \mathrm{A}$ & Brown. 2012 \\
\hline & Melbourne, Australia & 2013 & 75 & N/A & Imteaz et al. 2013 \\
\hline & Foshan, China & 2015 & 67 & $\mathrm{~N} / \mathrm{A}$ & Jia et al. 2015 \\
\hline & Cleveland, $\mathrm{OH}$ & 2015 & 80 & N/A & Jennings et al. 2015 \\
\hline & Guelph, Canada & 2017 & 44 & $20-510$ & Maxwell et al. 2017 \\
\hline \multirow{2}{*}{$\begin{array}{c}\text { Grass Swale } \\
\text { (2 Studies) }\end{array}$} & Various regions, US & 2008 & 50 & N/A & Barrett. 2008 \\
\hline & Foshan, China & 2015 & 42 & $\mathrm{~N} / \mathrm{A}$ & Jia et al. 2015 \\
\hline \multirow{2}{*}{$\begin{array}{l}\text { Detention } \\
\text { pond } \\
\text { (2 Studies) }\end{array}$} & Tampa, FL & 2001 & 30 & $\mathrm{~N} / \mathrm{A}$ & Rushton. 2001 \\
\hline & Piedmont, NC & 2012 & 56 & N/A & Line et al. 2012 \\
\hline Constructed & Coastal Plain, $\mathrm{NC}$ & 2011 & 54 & N/A & Lenhart and Hunt. 2011 \\
\hline $\begin{array}{l}\text { Wetland } \\
\text { (2 Studies) }\end{array}$ & Ashby, VA & 2017 & 43 & N/A & Schwartz et al. 2017 \\
\hline
\end{tabular}

\subsection{Literature Review for Meta-Analysis}

\subsubsection{Green Roof}

VanWoert et al. (2004) performed two studies to find the water retention effect of various treatments on rooftops. The first study examined three rooftop systems including: 1) a standard commercial roof with gravel ballast; 2) extensive green roof system without vegetation; and 3) a typical extensive green roof with vegetation. The second study tested the influence of roof slope and depth of green media on water retention capability. It concluded that the mean percent rainfall retention for green roof with vegetation is approximately $82.8 \%$. Another finding of the research was the confirmation that vegetated green roof not only can reduce the amount of runoff, but also extend the time before runoff occurs compared to a conventional commercial roof.

Connelly and Liu. (2005) conducted a research program to verify the performance of green roof and reduce the barriers toward its marketability. A green roof with 3" $(75 \mathrm{~mm})$ of growing medium can mitigate $95 \%$ of rainfall runoff in the first day of observed rainfall events over 30 measured days. The rainfall for the first measured day was $0.48 "(12.19 \mathrm{~mm})$ over a duration of 4 hours and 23 minutes. Overall, the tested green roof retained $67 \%$ of rainfall over the 30 measured days. 
Mentens et al. (2006) found that the retention capability of green roof performed better during the summer than winter. Using a study about the application of green roofs in Brussels, the research results showed a $2.7 \%$ runoff reduction with just $10 \%$ of green roof coverage and $54 \%$ for an individual building. Getter et al. (2007) studied the roof slope effect on mean retention and concluded a mean retention of $76.4 \%$ at $25 \%$ slope, with the highest retention of $85.6 \%$ at $2 \%$ slope. Bliss et al. (2008) constructed and monitored a prototype green roof in Pittsburgh, Pennsylvania. The results indicated a $70 \%$ runoff volume reduction compared to a conventional roof in the same test building. Simmons et al. (2008) compared the performance of six different extensive green roof designs vegetated with native species, to black roofs, and white roofs in Austin Texas. It was found that maximum run-off retention was $88 \%$ and $44 \%$ for medium and large rain events, respectively.

Roehr and Kong (2010) examined how distinct climatic conditions affect the runoff reduction of green roofs at three locations including Vancouver and Kelowna in British Columbia, and Shanghai, China. The results showed that that a typical green roof can reduce annual rooftop runoff by 29\% in Vancouver, 55\% in Shanghai and 100\% in Kelowna. Voyde et al. (2010) presented field monitoring results from a $235 \mathrm{~m}^{2}$, extensive living roof (also referred to as a green roof) in Auckland, New Zealand. The results indicated that the living roof retained a median of $82 \%$ of received rainfall per rainfall event. Carpenter and Kaluvakolanu (2011) investigated the roof reduction rate in Michigan. Overall, the researched green roof retained $68.25 \%$ of rainfall volume and reduced peak discharge by an average of $88.86 \%$. Gregoire and Clausen (2011) quantified runoff from a $248 \mathrm{~m}^{2}$ extensive green roof in Connecticut. It was found that the green roof retained $51.4 \%$ of precipitation during the study period. Stovin et al. (2012) conducted a laboratory experiment over 16-month period. They concluded that water retention capability can vary over different seasons and different rainfall patterns.

Graceson et al. (2013) conducted research to study the relationship between water retention capability with different types of growing media. Data was observed over a one-year period to find the relationship. The study concluded that decks were able to retain $44 \%$ of rain falling directly on their surface. More specifically, sedum decks retained $40 \%$ and meadow decks retained $48 \%$ of the rain. Morgan et al. (2015) studied green roofs with various media depth (plants depth) by performing a similar water retention capability study in Missouri over an 18 -month period. All of the green roofs studied in this experiment retained approximately $50 \%$ of the precipitation over the study period.

\subsubsection{Permeable Pavement}

Bond et al. (1999) conducted over thirteen years of research experiments to analyze rainfall and runoff reduction by adopting permeable pavements. Average runoff volumes between $34 \%$ and $47 \%$ were observed. Using a water balance study, it was concluded that the average water retention capability in the study area was $59.5 \%$. Research results not only indicated that permeable pavement performs well in rainfall runoff reduction, but also confirmed that permeable pavements are capable of degrading mineral oil contamination. Dreelin et al. (2006) compared the porous performance of an asphalt parking lot to a porous pavement parking lot of grass pavers in Athens, Georgia. The research results indicated that the porous parking lot produced $93 \%$ less runoff than the asphalt lot. In a study conducted by Ball and Rankin. (2010), effective imperviousness was reduced from $45 \%$ to $5 \%$ after the implementation of permeable pavement. The results found that a minimum of $1 / 6$ " $(4 \mathrm{~mm})$ of rain was required to consider significant rainfall, while a rainfall intensity in excess of $20 \mathrm{~mm} / \mathrm{hr}$. was necessary to generate surface runoff from a permeable road surface. Drake et al. (2014) evaluated the hydraulic performance of permeable pavement in Vaughan, Ontario and found that permeable pavement can reduce and completely capture overall storm water outflow volume by $43 \%$.

Imteaz et al. (2013) presented data measurements regarding the performance of permeable pavements used in Australia. The research revealed an average of $81 \%$ of runoff reduction by using permeable pavement. Yang et al. (2015) manifested a design rainfall intensity of $150 \mathrm{~mm} / \mathrm{hr}$. and found retention capabilities to vary within a range of $24.2 \%$ to $45.6 \%$ based on varying medium depth. Depth plays a significant role in controlling retention. According to an experiment conducted by Alsubih et al. (2016), the total rainwater volume temporarily retained in the experimental pavement structure ranged from $40 \%$ to $92 \%$ of the total inflow from different rainfall intensities. Winston et al. (2018) conducted research on the hydraulic performance of four permeable pavement sections revealing a volume reduction varying from $16 \%$ to $53 \%$ and peak flow reduction ranging from 69.7 to $100 \%$. Shafique et al. (2018) evaluated the hydraulic performance of permeable interlocking concrete pavement (PCIP). The experiment revealed that PCIP had $30 \%$ to $65 \%$ of runoff reduction performance during various storm events.

Collins et al. (2008) compared runoff reduction between asphalt and pervious concrete in terms of rainfall depth and found the percent of runoff reduction in asphalt to be $34.6 \%$, compared to $99.9 \%$ in pervious concrete. This translates to more than $60 \%$ percent of rainfall retained in pervious concrete compared to asphalt. Average percent 
volume reductions from rainfall were $35.7,43.9,66.3,63.6$, respectively for four types of permeable pavements analyzed.

\subsubsection{Bioretention (or Rain Garden)}

Li et al. (2009) studied six bioretention sites across Maryland and North Carolina to investigate the performance of rain gardens. Outflow and inflow data for each site were recorded to quantify performance. The results indicated that approximately $20 \%$ to $50 \%$ of runoff entering the rain garden was lost to exfiltration and evapotranspiration. Stander et al. (2010) conducted three experiments with different sizes of rain gardens including $2 \%, 4 \%$ and $6 \%$ of drainage area. The rain garden with $2 \%$ of drainage area undertook the maximum hydraulic loading compared to that with $6 \%$ drainage area. The study suggests that infiltration rates are not significantly different among different rain garden sizes. Maxwell et al. (2017) selected simple rain gardens as an alternative rainfall mitigation design for small-scale projects. In this research, they conducted five field studies to assess performance. The results indicated that simple rain gardens can retain an average of $44 \%$ of rainfall under a rain event of 1 " $(25 \mathrm{~mm})$.

\subsubsection{Detention Pond}

Rushton (2001) constructed an innovative parking lot in Tampa, Florida to demonstrate how a small modification in parking lot design can decrease the amount of storm water runoff. The research revealed that swales reduced on average $30 \%$ of storm water runoff at the study site. Line et al. (2012) installed a detention pond in a drainage area of 6.6 acres with a $90 \%$ imperviousness rate and found that the runoff rate was almost half of that on a control site containing no storm water control measures.

\subsubsection{Constructed Wetlands}

Lenhart and Hunt (2011) constructed and monitored a storm water wetland. Twenty hydrologic and eleven water quality events were captured and evaluated. The research concluded that the constructed wetland was very effective in storm water control with a reduction of $80 \%$ in outflow peak and $54 \%$ in runoff volume. Schwartz et al. (2017) constructed a retrofitted storm water retention pond located in a highly developed headwater watershed near the Potomac River. The results showed that the pond was capable of holding $43 \%$ of the average inflow during the study period.

\section{Discussion of Meta-Analysis Results}

The meta-analysis results indicate that all six runoff control and mitigation methods were effective for storm water runoff reduction. Runoff reduction performance varies with different scenarios and is usually published as a range. Averages of these ranges are presented in Table 2. The maximum reduction was found by applying Permeable pavement (Bean et al. 2007). More information about the reduction performance regarding all investigated methods can be found in Table 3. Figure 4 shows a boxplot distribution of runoff reduction performance for the analyzed mitigation methods. From Figure 4, the performance distribution using Green Roof shows a lower variability with half of the analyzed data having a consistent runoff control and mitigation performance ranging from $50 \%$ to $70 \%$, which suggests that this application is more likely to produce a desired reduction performance. Permeable pavement is not as consistent compared to Green Roof, as indicate by the box plot having a larger variation and median runoff reduction of $45 \%$, which is the lowest compared to the other five methods. Based on the meta-analysis, it can be concluded that Permeable pavement has a relative lower likelihood to produce a desired runoff control and mitigation outcome.

Table 3. Summary table for the runoff reduction performance of investigated methods

\begin{tabular}{ccccccc}
\hline $\begin{array}{c}\text { Mitigation } \\
\text { Method }\end{array}$ & $\begin{array}{c}\text { Green } \\
\text { Roof }\end{array}$ & $\begin{array}{c}\text { Permeable } \\
\text { Pavement }\end{array}$ & $\begin{array}{c}\text { Rain } \\
\text { Garden }\end{array}$ & $\begin{array}{c}\text { Grassed } \\
\text { Swale }\end{array}$ & $\begin{array}{c}\text { Detention } \\
\text { Pond }\end{array}$ & $\begin{array}{c}\text { Constructed } \\
\text { Wetland }\end{array}$ \\
\hline Maximum Reduction (\%) & 85 & 100 & 80 & 50 & 56 & 54 \\
Minimum Reduction (\%) & 29 & 30 & 35 & 42 & 30 & 43 \\
Average Reduction (\%) & 61 & 56 & 57 & 46 & 43 & 48.5 \\
\hline
\end{tabular}

Figure 4 indicates that all runoff control and mitigation methods are applicable; however, it is recommended to consider additional factors when selecting a specific method given the performance variation of using permeable pavement. Figure 5 illustrates the average percent reduction performance of all runoff control and mitigation methods by year analyzed. The overall average of $56.5 \%$ runoff control and mitigation rate for all analyzed methods reveals that more than half of the outflow from impermeable concrete, asphalt, rooftops, and roadways 
can be absorbed and retained by these methods.

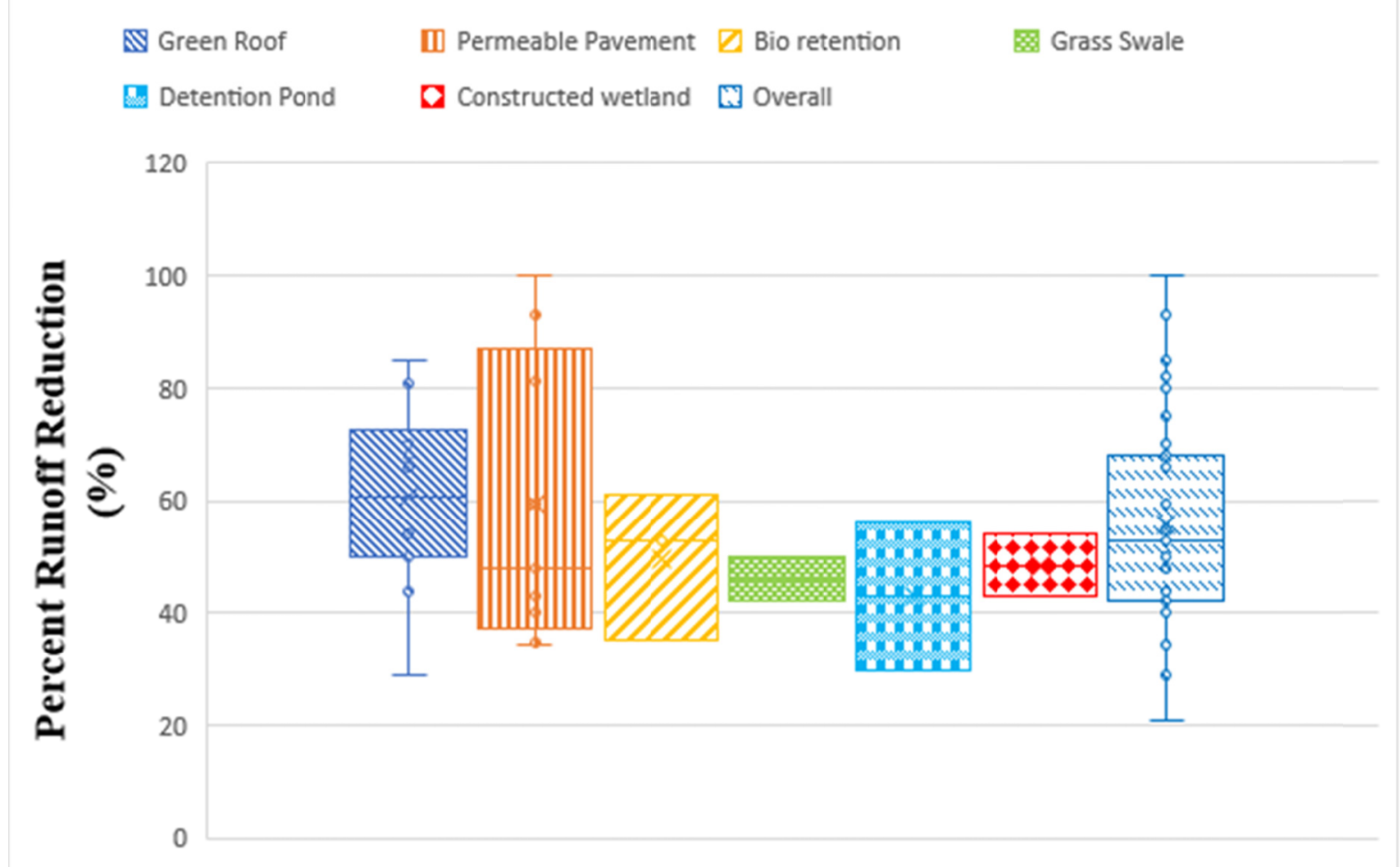

Figure 4. Box plot of percent runoff reduction for alternative strategies

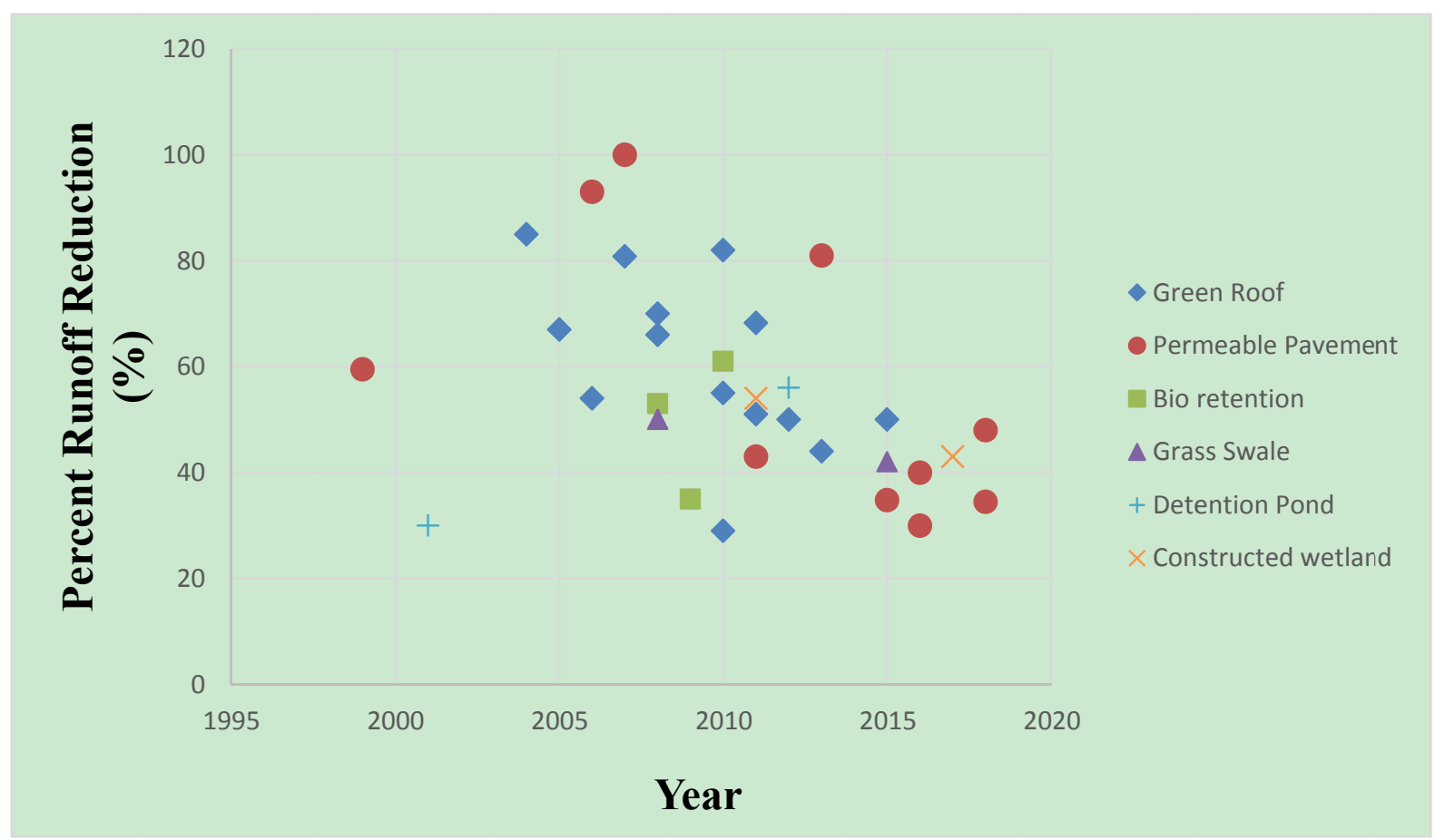

Figure 5. Average runoff reduction using alternative strategies

\section{Conclusions}

A meta-analysis of past and current state-of-practice in storm water impacts in urbanized cities was presented in 
this paper to gain a better understanding of this important topic. A review of runoff incidents and impacts on urban area reveals the destructive effects of excessive urban storm water. A sampling of cities was selected for analysis based on population and geographical region as part of the meta-analysis. There is no indication that urban growth will slow down anytime soon, thus resulting in more urban impervious areas being built and consequently, more pressure placed on urban drainage systems during significant rain events. Expanding the urban drainage system is not the only way to help alleviate these impacts. Several runoff control and mitigation strategies described in this paper have proven to reduce runoff volume and relieve hydraulic pressure on urban drainage systems. It is anticipated that city planners or authority organizations will better understand the benefits of such sustainable storm water runoff control and mitigation methods. It is recommended that future research be conducted to obtain additional data for the performance of different runoff control and mitigation methods including emerging state-of-art strategies. Furthermore, it is recommended that research be conducted on the performance of multiple methods for a given application to better understand their connectivity.

\section{References}

Ahiablame, L. M., Engel, B. A., \& Chaubey, I. (2012). Effectiveness of low impact development practices: literature review and suggestions for future research. Water Air Soil Pollut., 223, 4253-4273. https://doi.org/10.1007/s11270-012-1189-2

Alsubih, M., Arthur, S., Wright, G., \& Allen, D. (2016). Experimental study on the hydrological performance of a $\begin{array}{lllll}\text { permeable pavement. Urban Water } & \text { 427-434. }\end{array}$ https://doi.org/10.1080/1573062X.2016.1176221

Anderson, H. W., Hoover, M. D., \& Reinhart, K. G. (1976). Effects of forest management on floods, sedimentation, and water supply. USDA Forest Service General Technical Report.

Asleson, B. C., Nestingen, R. S., Gulliver, J. S., Hozalski, R. M., \& Nieber, J. L. (2009). Performance assessment of rain gardens. Journal of the American Water Resources Association, 45(4), 1019-1031. https://doi.org/10.1111/j.1752-1688.2009.00344.x

Ball, J. E., \& Rankin, K. (2010). The hydrological performance of a permeable pavement. Urban Water Journal, 7(2), 79-90. https://doi.org/10.1080/15730620902969773

Barrett, M. E. (2008). Comparison of bmp performance using the international bmp database. Journal of Irrigation and Drainage Engineering, 134(5), 556-561. https://doi.org/10.1061/(ASCE)0733-9437(2008)134:5(556)

Bean, E. Z., Hunt, W. F., \& Bidelspach, D. A. (2007). Field survey of permeable pavement surface infiltration rates. Journal of Irrigation and Drainage Engineering, 133, 247-255. https://doi.org/10.1061/(ASCE)0733-9437(2007)133:3(249)

Bliss, D. J., Neufeld, R. D., \& Ries, R. J. (2009). Storm water runoff mitigation using a green roof. Environ. Eng. Sci., 26(2), 407-417. https://doi.org/10.1089/ees.2007.0186

Bond, P. C., Pratt, C. J., \& Newman, A. (1999). A review of stormwater quantity and quality performance of permeable pavements in the UK. 8th International Conference on Urban Storm Drainage.

Brown, R. A., Line, D. E., \& Hunt, W. F. (2012). LID treatment train: pervious concrete with subsurface storage in series with bioretention and care with seasonal high water tables. Journal of Environmental Engineering, 138(6), 689-697. https://doi.org/10.1061/(ASCE)EE.1943-7870.0000506

Carpenter, D. D., \& Hallam, L. (2008). An investigation of rain garden planting mixture performance and the implication for design. International Low Impact Development Conference, 1-10. https://doi.org/10.1061/41009(333)2

Carpenter, D. D., \& Kaluvakolanu, P. (2011). Effect of roof surface type on storm-water runoff from full-scale roofs in a temperate climate. Journal of Irrigation and Drainage Engineering, 137, 161-169. https://doi.org/10.1061/(ASCE)IR.1943-4774.0000185

Carson, H., Eaker, B., Gibson, P., \& Randall, M. (2010). Stormwater problems and impacts: why all the fuss? North Carolina Division of Water Quality Stormwater Unit: Manuals and Factsheets. Retrieved from http://riverlink.org/wp-content/uploads/2014/01/stormwaterseriesfinall.pdf

Chapman, C., \& Horner, R. R. (2010). Performance assessment of a street-drainage bioretention system. Water Environment Research, 82(2), 109-119. https://doi.org/10.2175/106143009X426112

China flooding: Wuhan on red alert for further rain. Retrieved May 27, 2018, from http://www.bbc.com/news/world-asia-china-36721514 
Chocat, B., Ashley, R., Marsalek, J., Matos, M. R., Rauch, W., Schilling, W., \& Urbonas, B. (2007). Toward the sustainable management of urban storm-water. Indoor Built Environ., 16, 273-285. https://doi.org/10.1177/1420326X07078854

Collins, K., Hunt, W. F., \& Hathaway, J. M. (2008). Hydrologic comparison of four types of permeable pavement and standard asphalt in eastern North Carolina. J. Hydrol. Eng., 13(12), 1146-1157. https://doi.org/10.1061/(ASCE)1084-0699(2008)13:12(1146)

Connelly, M., \& Liu, K. (2005). Green roof research in British Columbia- an overview. New Directions in Green Roof Research. Retrieved from https://commons.bcit.ca/greenroof/files/2012/01/3.2_connelly_lui.pdf

Cutlip, J. (2006). Green roofs: a sustainable technology. Retrieved from https://extension.ucdavis.edu/sites/default/files/green_roof.pdf

Drake, J., Bradford, A., \& Seters, T. V. (2014). Hydrologic performance of three partial-infiltration permeable pavements in a cold climate over low permeability soil. Journal of Hydrologic Engineering, 19(9). https://doi.org/10.1061/(ASCE)HE.1943-5584.0000943

Dreelin, E. A., Fowler, L., \& Carroll, C. R. (2006). A test of porous pavement effectiveness on clay soils during natural storm events. Water Research, 40(4), 799-805. https://doi.org/10.1016/j.watres.2005.12.002

Eckart, K., McPhee, Z., \& Bolisetti, T. (2017). Performance and implementation of low impact development - A review. Science of the Total Environment, 413-432. https://doi.org/10.1016/j.scitotenv.2017.06.254

Environmental Protection Agency (EPA). (2012). Benefits of low impact development. Retrieved from https://www.epa.gov/sites/production/files/2015-09/documents/bbfs1benefits.pdf

Getter, K. L., Rowe, D. B., \& Andresen, J. A. (2007). Quantifying the effect of slope on extensive green roof stormwater retention. Ecological Engineering, 31(4), 225-231. https://doi.org/10.1016/j.ecoleng.2007.06.004

Graceson, A., Hare, M., Monaghan, J., \& Hall, N. (2013). The water retention capabilities of growing media for green roofs. Ecological Engineering, 61, 328-334. https://doi.org/10.1016/j.ecoleng.2013.09.030

Gregoire, B. G., \& Clausen, J. C. (2011). Effect of a modular extensive green roof on stormwater runoff and water quality. Ecological Engineering, 37(6), 963-969. https://doi.org/10.1016/j.ecoleng.2011.02.004

Hurricane Harvey. In Wikipedia. Retrieved May 27, 2018, from https://en.wikipedia.org/wiki/Hurricane_Harvey

Huoche News about extreme events in Guangzhou. (2017). 2017.5.7 Guangzhou torrential rain latest new. Retrieved from https://www.huoche.net/show_509179/

Huong, H. T. L., \& Pathirana, A. (2013). Urbanization and climate change impacts on future urban flooding in Can Tho City, Vietnam. Hydrol. Earth Syst. Sci., 17, 379-394. https://doi.org/10.5194/hess-17-379-2013

Hundecha, Y., \& Bárdossy, A. (2004). Modeling of the effect of land use changes on the runoff generation of a river basin through parameter regionalization of a watershed model. Journal of Hydrology, 292, 281-295. https://doi.org/10.1016/j.jhydrol.2004.01.002

Imteaz, M. A., Ahsan, A., Rahman, A., \& Mekanik, F. (2013). Modelling stormwater treatment systems using music: accuracy. Resources, Conservation and Recycling, 71, 15-21. https://doi.org/10.1016/j.resconrec.2012.11.007

Jaber, F. (2008). Stormwater management. Texas A\&M Agrilife Extension, TX.

Jennings, A. A., Berger, M. A., \& Hale, J. D. (2015). Hydraulic and hydrologic performance of residential rain $\begin{array}{llll}\text { gardens. Journal of Environmental } & \text { Engineering, } & \text { 141(11). }\end{array}$ https://doi.org/10.1061/(ASCE)EE.1943-7870.0000967

Jia, H. F., Wang, X. W., Ti, C. P., Zhai, Y. Y., Field, R., Tafuri, A. N. .. Yu, S. L. (2015). Field monitoring of a LID-BMP treatment train system in China. Environ Monit Assess., 187(6), 373. https://doi.org/10.1007/s10661-015-4595-2

July 2012 Beijing flood. Wikipedia. In Wikipedia. Retrieved May 27, 2018, from https://en.wikipedia.org/wiki/July_2012_Beijing_flood

Lenhart, H. A., \& Hunt, W. F. (2011). Evaluating four storm-water performance metrics with a North Carolina coastal plain storm water wetland. Journal of Environmental Engineering, 137(2), 155-162. https://doi.org/10.1061/(ASCE)EE.1943-7870.0000307

Li, H., Sharkey, L. J., Hunt, W. F., \& Davis, A. P. (2009). Mitigation of impervious surface hydrology using 
bioretention in North Carolina and Maryland. Journal of Hydrologic Engineering, 14(4). https://doi.org/10.1061/(ASCE)1084-0699(2009)14:4(407)

Line, D. R., Brown, R. A., Hunt, W. F., \& Lord, W. G. (2012). Effectiveness of lid for commercial development in North Carolina. Journal of Environmental Engineering, 138(6), 680-688. https://doi.org/10.1061/(ASCE)EE.1943-7870.0000515

Markovic, G., Zelenakova, M., Kaposztasova, D., \& Hudakova, G. (2014). Rainwater infiltration in the urban areas. WIT Transactions on Ecology and the Environment, 181. https://doi.org/10.2495/EID140271

Maxwell, A., Harder, L., \& Zheng, Y. B. (2017). Investigating the performance of simple rain gardens in Guelph. (Unpublished master's thesis). University of Guelph, Ontario, Canada.

Mentens, J., Raes, D., \& Hermy M. (2006). Green roofs as a tool for solving the rainwater runoff problem in the urbanized 21st century. Landscape and Urban Planning, 77(3), 217-226. https://doi.org/10.1016/j.landurbplan.2005.02.010

Morgan, S., Celik, S., \& Retzlaff, W. (2013). Green roof storm-water runoff quantity and quality. Journal of Environmental Engineering, 139(4), 471-478. https://doi.org/10.1061/(ASCE)EE.1943-7870.0000589

New Jersey Department of Environmental Protection. (NJDEP). (2017). New Jersey storm water best management practices manual. Retrieved from http://www.njstormwater.org/bmp_manual2.htm

Nazir, T., \& Sharma, C. M. (2015). Rate of infiltration under different forest covers of Garhwal Himalaya. The Indian Forester, 141(9), 930-940.

Ohana-Levi, N., Givati, A., Alfasi, N., Peeters, A., \& Karnieli, A. (2017). Predicting the effects of urbanization on runoff after frequent rainfall events. Journal of Land Use Science. https://doi.org/10.1080/1747423X.2017.1385653

Penn, M., \& Parker, P. J. (2011). Introduction to infrastructure: an introduction to civil and environmental engineering. Jogn Wiley and Sons, Inc. New Jersey.

Qianjiang News about heavy rain in Quzhou. (2017). Retrieved from http://zj.qq.com/a/20170626/012696.htm

Riemann, A. (2016). The performance and sustainability of permeable pavement. Progress Report on the Work Performed Under IAPA Scholarship.

Roehr, D., \& Kong, Y. (2010). Runoff reduction effects of green roofs in Vancouver, BC, Kelowna, BC, and Shanghai, P.R. China. Canadian Water Resources Journal, 35(1), 53-67. https://doi.org/10.4296/cwrj3501053

Rushton, B. (2001). Low-impact parking lot design reduces runoff and pollutant loads. Journal of Water Resources Planning and Management, 127(3), 172-179. https://doi.org/10.1061/(ASCE)0733-9496(2001)127:3(172)

Sample, D. J. (2013). Best management practice fact sheet 1: rooftop disconnection. Virginia cooperative extension, 426-119.

Schwartz, D., Sample, D. J., \& Grizzard, T. J. (2017). Evaluating the performance of a retrofitted stormwater wet pond for treatment of urban runoff. Environ Monit Assess., 189-256. https://doi.org/10.1007/s10661-017-5930-6

Selbig, W. R., \& Balster, N. (2010). Evaluation of turf-grass and prairie-vegetated rain gardens in a clay and sand soil, Madison, Wisconsin, water years 2004-08. Scientific Investigations Report 2010-5077. https://doi.org/10.3133/sir20105077

Shafique, M., Kim, R., \& Kyung-Ho, K. (2018). Rainfall runoff mitigation by retrofitted permeable pavement in an urban area. Sustainability, 10, 1-10. https://doi.org/10.3390/su10041231

Simmons, M. T., Gardiner, B., Windhager, S., \& Tinsley, J. (2008). Green roofs are not created equal: the hydrologic and thermal performance of six different extensive green roofs and reflective and non-reflective roofs in a sub-tropical climate. Urban Ecosystems, 11(4), 339-348. https://doi.org/10.1007/s11252-008-00694

Stander, E. K., Borst, M., Connor, T. P., \& Rowe, A. A. (2010). The effects of rain garden size on hydrologic performance. World Environmental and Water Resources Congress 2010. https://doi.org/10.1061/41114(371)309

Stovin, V., Vesuviano, G., \& Kasmin, H. (2012). The hydrological performance of a green roof test bed under UK climatic conditions. Journal of Hydrology, 414-415, 148-161. https://doi.org/10.1016/j.jhydrol.2011.10.022 
Struck, S. D. (2007). Approaches for determining swale performance for stormwater runoff. Proceedings World Environmental and Water Resources Congress 2007. Tampa, FL. 1-9. https://doi.org/10.1061/40927(243)41

Sun, Z. C., Li, X. W., Fu, W. X., Li, Y. K., \& Tang, D. S. (2013). Long-term effects of land use/land cover change on surface runoff in urban areas of Beijing, China. Journal of Applied Remote Sensing, 8(1). https://doi.org/10.1117/1.JRS.8.084596

Tylor, M., Mulholland, M., \& Thornburrow, D. (2009). Infiltration characteristics of soils under forestry and agriculture in the upper Waikato catchment. Environment Waikato Technical Report 2009/18.

VanWoert, N. D., Rowe, D. B., Andresen, J. A., Rugh, C. L., Fernandez, R. T., \& Xiao, L. (2004). Green roof stormwater retention: effects of roof surface, slope, and media depth. Journal of Environmental Quality, 34(3), 1036-1044. https://doi.org/10.2134/jeq2004.0364

Voyde, E., Fassman, E., \& Simcock, R. (2010). Hydrology of an extensive living roof under subtropical climate conditions in Auckland, New Zealand. Journal of Hydrology, 394, 384-395. https://doi.org/10.1016/j.jhydrol.2010.09.013

Wallace, J. (2013). Litter ruins city drainage system. Albany, Georgia. WALB News. Retrieved from http://www.walb.com/story/23242150/litter-ruins-city-drainage-system/

Winston, R. J., Dorsey, J. D., Smolek, A. P., \& Hunt, W. F. (2018). Hydrologic performance of four permeable pavement systems constructed over low-permeability soils in northeast Ohio. Journal of Hydrologic Engineering, 23(4). https://doi.org/10.1061/(ASCE)HE.1943-5584.0001627

Xiao, Q. F., \& McPherson, E. G. (2016). Surface water storage capacity of twenty tree species in Davis, California. Journal of Environmental Quality, 45, 188-198. https://doi.org/10.2134/jeq2015.02.0092

Xinhua News reports heavy rain in Hunan. (2017) Retrieved May 27, 2018, from http://www.xinhuanet.com/politics/2017-06/24/c_1121203691.htm

Yang, W. Y., Li, D., Sun, T., \& Ni, G. H. (2015). Saturation-excess and infiltration-excess runoff on green roofs. Ecological Engineering, 74, 327-336. https://doi.org/10.1016/j.ecoleng.2014.10.023

Zhou, Q. Q. (2014). A review of sustainable urban drainage systems considering the climate change and urbanization impacts. Water, 6, 976-992. https://doi.org/10.3390/w6040976

\section{Copyrights}

Copyright for this article is retained by the author(s), with first publication rights granted to the journal.

This is an open-access article distributed under the terms and conditions of the Creative Commons Attribution license (http://creativecommons.org/licenses/by/4.0/). 